\title{
A Free Ride and Lunch: Stylopization in the Solitary Hunting Wasp, Ammophila Fernaldi Murray and A. Pictipennis (Walsh) (Hymenoptera: Sphecidae) By Paraxenos Lugubris Pierce (Strepsiptera)
}

\author{
Author(s): Jeyaraney Kathirithamby, Gary K. Lechner, Dino P. Mcmahon, \\ Alexandra L. Bryson and J. Spencer Johnston \\ Source: Proceedings of the Entomological Society of Washington, \\ 114(4):464-475. 2012. \\ Published By: Entomological Society of Washington \\ URL: http://www.bioone.org/doi/full/10.4289/0013-8797.114.4.464
}

BioOne (www.bioone.org) is a nonprofit, online aggregation of core research in the biological, ecological, and environmental sciences. BioOne provides a sustainable online platform for over 170 journals and books published by nonprofit societies, associations, museums, institutions, and presses.

Your use of this PDF, the BioOne Web site, and all posted and associated content indicates your acceptance of BioOne's Terms of Use, available at www.bioone.org/page/ terms of use.

Usage of BioOne content is strictly limited to personal, educational, and non-commercial use. Commercial inquiries or rights and permissions requests should be directed to the individual publisher as copyright holder. 
PROC. ENTOMOL. SOC. WASH.

114(4), 2012, pp. 464-475

\title{
A FREE RIDE AND LUNCH: STYLOPIZATION IN THE SOLITARY HUNTING WASP, AMMOPHILA FERNALDI MURRAY AND A. PICTIPENNIS (WALSH) (HYMENOPTERA: SPHECIDAE) BY PARAXENOS LUGUBRIS PIERCE (STREPSIPTERA)
}

\author{
Jeyaraney Kathirithamby, Gary K. Lechner, Dino P. McMahon, \\ Alexandra L. Bryson, and J. Spencer Johnston
}

(JK, DPM, ALB) Department of Zoology, South Parks Road, Oxford OX1 3PS, U.K. (e-mail: Jeyaraney.kathirithamby@zoo.ox.ac.uk; dino.mcmahon@gmail.com; abryson@ mail.med.upenn.edu); (GKL) 3624 Virginia St. Sioux City, Iowa 51104, U.S.A. (e-mail: lechnerg_wcqma@yahoo.com); (JSJ) Department of Entomology, Texas A \& M University 2475, College Station, Texas 77843, U.S.A. (e-mail: spencerj@tamu.edu)

Abstract. - The intricate nest building, cleaning and provisioning habits of the solitary hunting wasps Ammophila fernaldi Murray and A. pictipennis (Walsh) (Hymenoptera: Sphecidae) are supposed to have developed in response to parasite pressure. This paper presents the first study to record the behavior of phoresy of Paraxenos lugubris Pierce (Strepsiptera: Stylopidae). Adapting to the provisioning of single-cell nests of the Ammophila sp., it is the tiny, free-living, first instar larvae of P. lugubris, that are phoretic. They are carried, not by a wasp stylopized by a female $P$. lugubris producing first instar larvae, but by an unstylopized foraging wasp, thereby discreetly gaining entry to a single-cell nest before it is sealed. Multiple first instar P. lugubris larvae are often taken by the host, A. fernaldi and A. pictipennis, to the single egg/ larvae in the cell, resulting in superparasitism. These observations further demonstrate that Strepsiptera have developed mechanisms for parasitizing a range of hosts, including solitary wasps that develop in sealed cells.

Key Words: phoresy, superparasitism

DOI: 10.4289/0013-8797.114.4.464

"... the philosopher, racking his brain over the nature of instinct, will award the palm to the operations of the Hunting Wasps. . Nowhere do I find a more brilliant, more lucid, more eloquent proof of the inituitive wisdom of instinct; nowhere does the theory of evolution suffer a more obstinate check" - Jean-Henri Fabre (1920).

The solitary hunting wasp Ammophila sp. (Sphecidae) has been reported to have cuckoo and brood parasites (Diptera: Sarcophagidae; Hymenoptera: Chrysididae)
(Hager and Kurczewski 1985, Rosenheim 1987, Field 1989a, 1989b; Field and Brace 2004), but only one endoparasitoid, the Strepsiptera (Evans and West Eberhart 1970). The elaborate nest building, provisioning and cleaning behavior of the ground-nesting, solitary, hunting wasp Ammophila sp. have been explained as possible responses to parasite pressure (Rosenheim 1987). In spite of this, Strepsiptera are here recorded as able to enter the nests by phoresy, to parasitize 
the immature stages of these wasps. The term phoresy is regularly used to include transport (both external and internal) of an insect by another insect other than its specific host, which is essential for the developmental cycle of the insect being transported (Clausen 1976). This term is now used for the transportation of insects by their specific hosts, and, if the insect happens to be a parasite/parasitoid, phoresy is of disadvantage to the progeny of its carrier, since the egg/larval stages of the host are parasitized when the parasite/ parasitoid reaches its destiny. This means of transport is vital for parasitic insects that have free-living first instar larvae, such as the coleopteran Meloidae and Rhipiphoridae, the hymenopteran Eucharitidae, and the strepsipteran Stylopidae (Clausen 1976). To complete their life cycle, the free-living first instar larvae have to reach the egg/larval stages of the host, which in discrete temporal habitats such as nests of arthropods are some distance removed from the habitat from where the first instars emerged (Clausen 1976, Houck and O'Connor 1971).

Strepsiptera parasitize thirty four families of Insecta, and their life cycle has been seen to be co-adapted to that of their hosts (Kathirithamby 2009). They have a wide host range, which include apterygotes, exo-, and endopterygotes. Of the endopterygotes, Strepsiptera parasitize Diptera and Hymenoptera (both eusocial and solitary wasps and bees) (Kathirithamby 2009). Of the latter hosts, parasitization of new hosts is complex, since no horizontal transmission takes place in the nest. Stylopized hosts, on emergence from the pupal stage, will leave the nest: the male strepsipteran will extrude the anterior region of the pupa and commence pupation, while the female will extrude the head and anterior thoracic region and become a endoparasitic, neotenic female. The strepsipteran male will emerge from the endoparasitic pupal case and seek a female to fertilize. Upon fertilization, viviparous development will take place, and the first instars emerge to be dispersed by the host wasp. As dispersal of first instars occurs outside the nest, a means of transport is essential if the insects are to reach and parasitize the next generation of host larvae which are within the nest. One particularly interesting aspect of stylopization in Hymenoptera is this mode of transfer of the first instar larvae to the nest.

As early as 1924, Hughes-Schrader observed that the female of the eusocial wasp Polistes, parasitized by Xenos peckii Kirby, came out of winter hibernation but did not make nests. Kirby further observed that, in the summer, colonies parasitized Polistes (with several emerging $X$. peckii first instars), remained close to the nest, and returned to it for long periods, and it was suggested that the parasitized Polistes served to carry the first instars directly to the nest. Similarly, in the eusocial wasp Polistes dominulus Christ, phoresy was the assumed mode of transfer of the first instar larvae of $X$. vesparum Rossi to the nest. However, Pardi (1946) observed that stylopized $P$. dominulus moved from one nest to another, but did not behave as foundresses, nor act as nest builders. In 2003, Hughes et al. reported that nests visited by parasitized wasps had high infections of $X$. vesparum. The transfer of the first instar larvae of $P$. dominulus parasitized by $X$. vesparum revealed that mature female adult $X$. vesparum (with first instar larvae) endoparasitic in their hosts, move with the host to new nests, where the first instars would emerge from the female strepsipteran to invade new eggs/larvae in the cells. This transfer by stylopized wasps of first instar larvae to nests was speculatively taken to be an effective dispersal mechanism of $X$. vesparum by $P$. dominulus, and might, it was suggested, be universal in eusocial wasps (Hughes et al. 2003). 
Only occasional sightings of first instar strepsipteran larvae attached to unstylopized hosts have been made so far, in either solitary or eusocial wasps. Maeta et al. (2001) found only one unstylopized female Pseudoxenos iwatai Esaki with the first instar of Rhynchium quinquecinctum Sk., and Hughes et al. (2003) also observed only a few unstylopized $P$. dominulus with first instars attached to them.

Linsley and McSwain (1957) reported phoresy whereby the first instar larvae of Stylops pacificus Bohart are taken along with the nectar into the honey stomach of the host Andrena complexa Viereck and then regurgitated onto the pollen ball in the nest. Subsequently, Batra (1963) found first instar larvae of Halictoxenos jonesi Pierce in the crop of the Halictidae bee Lasioglossum zephyrum (Smith) and similarly speculated that the first instars were transported along with the honey and regurgitated onto the pollen ball in the nest. Serini et al. (1996) reported that the pollen load of Apis mellifera $\mathrm{L}$. from the central Italian Alps had three species of Strepsiptera which are known parasites of Andrena sp. and Odynerus sp. and suggested that the first instars were among the pollen in the flowers which was visited by the Apis bee.

Except for the recorded prevalence of stylopization in Sphex ichneumoneus (L.) (Miller et al. 2009), virtually nothing is known about the details of stylopization in solitary hunting Sphecidae (Table 3 ) in the USA. No observations of phoresy have been made in the solitary bees and hunting wasps of the subfamilies Sphecidae (wasps) and Andrenidae (bees) parasitized by Strepsiptera (Table 3) from the European or American regions.

We here document for the first time: (i) phoresy (whereby several unstylopized hosts have first instar larvae attached to them), (ii) the rate of parasitism, and (iii) superparasitism in two species of solitary wasps, Ammophila fernaldi Murray (new record) and A. pictipennis (Walsh) by the strepsipteran Paraxenos lugubris (Pierce). We also provide the first description of the first instar larva, the male, and a redescription of the female P. lugubris.

Table 1. Ammophila fernaldi (Af), A. pictipennis (Ap) total Ammohila sp. parasitized by Paraxenos lugubris (Pl)

\begin{tabular}{|c|c|c|c|}
\hline \multicolumn{4}{|c|}{ Ammophila (Paraxenos lugubris o", ९) Paraxenos lugubris on $0^{*}, \bigcirc$ host } \\
\hline State & Females $(\mathrm{N})$ & Males (N) & Phoretic first instar of $P l^{* . \#}$ \\
\hline \multirow[t]{3}{*}{ Stylopized } & 39 Af $\left(330^{\prime \prime}, 42\right.$ ㅇ, 1?) & 22 Af $\left(150^{n}, 11 q, 1 ?\right)$ & 111 on 8 ㅇ stylopized $A f$ \\
\hline & 19 Ap $\left(17 \sigma^{*}, 20 \%\right)$ & $12 \operatorname{Ap}\left(3 \sigma^{\prime \prime}, 1\right.$ ) $)$ & 168 on 3 Q stylopized $A p$ \\
\hline & $58 \operatorname{Am}\left(500^{*}, 62 Q, 1 ?\right)$ & $34 \operatorname{Am}\left(180^{*}, 12 q, 1 ?\right)$ & $\begin{array}{l}279 \text { on } 11 \text { o stylopized } \\
A m \text { spp }\end{array}$ \\
\hline \multirow[t]{3}{*}{ Unstylopized } & 29 Af $\left(0 \sigma^{*}, 0 q\right)$ & 49 Af $\left(0 \sigma^{*}, 0 q\right)$ & 94 on $7 \sigma^{\prime \prime}, 13$ ? unstylopized $A f$ \\
\hline & $24 \mathrm{Ap}\left(0 \mathrm{O}^{x}, 0\right.$ 0 ) & $3 A p\left(0 \sigma^{n}, 0 q\right)$ & 14 on $10^{\prime \prime}, 69$ unstylopized $A p$ \\
\hline & $53 \mathrm{Am}\left(00^{\star}, 0 \%\right)$ & $52 A m\left(00^{*}, 0 \%\right)$ & $\begin{array}{l}108 \text { on } 80^{*}, 199 \text { unstylopized } \\
\quad A m \text { spp. }\end{array}$ \\
\hline \multirow[t]{3}{*}{ Total } & 68 Af $\left(330^{\prime \prime}, 42\right.$ ㅇ, 1?) & 67 Af $\left(150^{n}, 11\right.$,, $\left.1 ?\right)$ & 205 on $70^{\prime \prime}, 21$ ? stylopized $A f$ \\
\hline & 43 Ap $\left(17 \sigma^{*}, 20 q\right)$ & $6 A p\left(3 \sigma^{*}, 1\right.$ $)$ & 182 on $10^{\star}, 9$ stylopized $A p$ \\
\hline & $111 \operatorname{Am}\left(50 \sigma^{*}, 62\right.$,, $\left.1 ?\right)$ & $73 \mathrm{Am}\left(180^{\pi}, 12 \%, 1 ?\right)$ & 387 on $80^{\prime \prime}, 30$ A $A m$ spp. \\
\hline
\end{tabular}

\footnotetext{
135 Af (103 P. lugubris including 480", 53\%, 2?)

49 Ap (41 P. lugubris including 200", 21\%)

184 Ammophila sp. (144 P. lugubris including 680", 74 + 2 immature - unknown sex)

"First instars that were emerging from female P. lugubris

\# First instars that were attached to host Ammophila sp.
} 


\section{Material ANd Methods}

The collections were carried out by G. K. Lechner in Iowa, Sioux City, USA. The collecting site was visited once or twice daily on 113 days in 2008 between $16^{\text {th }}$ June and $25^{\text {th }}$ October. Two visits per day were rare (only 6 days of the 113). At no time was the site visited any earlier than $08.30 \mathrm{hrs}$ or any later than $19.45 \mathrm{hrs}$. Most commonly, visits were made between $10.00 \mathrm{hrs}$ and $15.00 \mathrm{hrs}$. A visit could be as short as 2-5 minutes or as long as 30-35 minutes, with the norm for time spent per visit of 15-20 minutes.

Host Ammophila were netted at flowers and, wherever observed, placed into alcohol, identified to species and sent to JK for dissecting to score for the presence of Strepsiptera. Endoparasitic P. lugubris larvae were scored as to sex whenever possible: neotenic female $P$. lugubris were identified by the extruded cephalothorax, and male $P$. lugubris by the presence of the cephalotheca, or an empty puparium.

Five species of Paraxenos which parasitize Ammophila sp. have been described thus far (Table 4). The protocols employed for amplification and sequencing mtDNA for identification of Paraxenos to species follow McMahon et al. (2009). The cytochrome c oxidase 1 (cox1) primer pair Jerry (F) (Simon et al. 1994) and cox1 $1265(\mathrm{R})$ (designed with reference to an alignment of insect cox1) was used to amplify 390 nucleotides from the mtDNA of Paraxenos specimens, stylopizing $A$.

Table 2. Superparasitism in Ammophila fernaldi and A. pictipennis by the Paraxenos lugubris. (The number expected in parentheses)

\begin{tabular}{|c|c|c|c|}
\hline \multicolumn{4}{|c|}{ No./host } \\
\hline No. of $Q /$ host & 0 or/host & $1 \sigma^{n / h o s t}$ & $2+\sigma^{x} /$ host \\
\hline 0 Q/host & 106(99.0) & $24(27.5)$ & $7(10.0)$ \\
\hline 1 Q/host & $16(18.8)$ & $6(5.2)$ & $4(2.0)$ \\
\hline $2+Q /$ host & $11(15.1)$ & $7(4.2)$ & $3(1.6)$ \\
\hline
\end{tabular}

$\left(\chi^{2}=8.88,4 \mathrm{df}, P=0.064\right)$ fernaldi and A. pictipennis, respectively. The cox 1 sequences amplified from Paraxenos stylopizing $A$. fernaldi and A. pictipennis were identical for all 390 nucleotides (Appendix 1). Given morphological and sequence identity, we conclude that both Ammophila species are parasitized by a single inter-mating population of P. lugubris.

\section{Results}

Family Xenidae (Saunders 1872)

Paraxenos lugubris (Pierce 1908)

(Figs. 1-8)

Diagnosis.- In contrast with P. lugubris, basal segment of maxilla is a quarter of the length of the palps in $P$. sphecidarium and two thirds the length in $P$. sinuatus. In $P$. sphecidarium and $P$. sinuatus, the flabellum on III antennomere a little shorter than the IV and postlumbium very narrow.

Description.-Adult Male (Fig. 1). Flabellum on antennomere III slightly longer than IV $(111=0.60-0.61 \mathrm{~mm})$; $\mathrm{IV}=0.54-0.55 \mathrm{~mm})$. Mandibles $=0.21-$ $0.22 \mathrm{~mm}$ ); basal maxillary segment and palpi of equal length (0.07-0.08mm). Scutum $=0.22-0.23 \mathrm{~mm})$; scutellum $=$ $0.44-0.46 \mathrm{~mm}$; postlumbium length = $0.04 \mathrm{~mm}$, width $==0.45-046 \mathrm{~mm}$; postnotum $=0.70 \mathrm{~mm}(n=10)$.

Male cephalotheca (Fig. 2). Total length (along central position) $=0.68 \mathrm{~mm}$, width $($ greatest width $)=0.84 \mathrm{~mm}$. Rudiments of ommatidia represented by thickenings. Antennal rudiments round. Mandibles with a single spine, a mouth opening lies between the mandibles and maxilla.

Female cephalothorax (Fig. 3). Dark, length (along central position) $=1.41-$ $0.46 \mathrm{~mm}$; width (greatest width) $=1.22-$ $1.25 \mathrm{~mm}(\mathrm{n}=10)$. Hypopharynx between a pair of mandibles. Brood canal opening narrow (length $=250 \mu \mathrm{m}$; width $=100 \mu \mathrm{m}$, at mid point). A pair of spiracles on either 
Table 3. Solitary and social wasps/bees parasitized by Strepsiptera (Stylopidae and Xenidae) (after Kinzelbach 1971)

\begin{tabular}{clll}
\hline Family & \multicolumn{1}{c}{ Subfamily } & \multicolumn{1}{c}{ Genus } \\
\hline \multirow{2}{*}{ Andrenidae } & Panurginae & Panurgus, Pseudopanurgus & Crawfordia \\
Andrenidae & Andreninae & Andrena & Stylops \\
& Panurginae & Melitturga & Kinzelbachus \\
Colletidae & Hylaeinae & Hylaeus & Helecthrus \\
Halictidae & Rophitinae & Conanthalictus, Dufourea & Eurystylops \\
& Halictinae & Lasioglossum, Augochloropsis & Halictoxenos \\
Sphecidae & Bembicinae & Stizus, Bembix, Bembecinus & Paraxenos \\
& Sphecinae & Sphex, Isodontia, Prionyx, & Paraxenos \\
& Sceliphrinae & Sceliphron & Paraxenos \\
& Ammophilinae & Ammophila, Podalonia & Paraxenos \\
Vespindae & Crabroninae & Tachytes & Paraxenos \\
Melittidae & Masarinae & ? & Pseudoxenos \\
& Eumeninae & Enodynerus, Anterhynchium & Pseudoxenos \\
& & Odynerus, Ancistrocerus Rynchium, & \\
& & Eumenes, Pachodynerus & Mdontodynerus, Montezumia, \\
\end{tabular}

side. Nassonow glands (ca. 16) on dorsal surface (Fig. 4).

First instar larva (Figs. 5-8). Length $=$ 249-250 $\mu \mathrm{m}(\mathrm{n}=10)$. A pair of maxillary palps with setae. Dorsal abdominal tergites almost smooth, sternites with about
4 spines. Intercoxal sternites elongated, with a few spines (Figs. 5-8). Six short, and two long spines on the coxa. Pro- and mesothoracic tarsi enlarged, rounded with a dorsal plate with spurs, and esotomoracic tarsi elongated and rod-like. Spurs on

Table 4. List of Ammophila sp. parasitized by Paraxenos (Strepsiptera: Paraxeninae)

\begin{tabular}{|c|c|c|}
\hline Species of Paraxenos & Species of Ammophila & Distribution \\
\hline $\begin{array}{l}P . \text { inclusus }(\text { Oliveria and Kogan } 1963) \\
P . \text { lugubris }(\text { Pierce 1908) } \\
=P . \text { pruinosae }(\text { Pierce } 1909) \\
=P . \text { pictipennis } \text { (Pierce } 1911) \\
=P . \text { vulgaridis } \text { (Pierce } 1911)\end{array}$ & $\begin{array}{l}\text { Ammophila sp. } \\
\text { A. punctaticeps Arnold } \\
\text { A. heydeni Dahlbom } \\
\text { A. nasuta Lepeletier } \\
\text { A. pubescebs Curtis } \\
\text { A. sabulosa (Linneaus) } \\
\text { A. terminate Smith } \\
\text { Ammophila } \text { sp. } \\
\text { A. berti Haldeman } \\
\text { A. arvensis Lepeletier, } \\
\text { A. breviceps } \text { F. Smith, } \\
\text { A. gracilis Lepeletier, } \\
\text { A. kennedyi Murray, } \\
\text { A. nasalis Provancher, } \\
\text { A. placida } \text { F. Smith, } \\
\text { A. pruinosa Cresson, A. urnaria Dahlbom } \\
\text { A. pictipennis (Walsh) (this study) } \\
\text { A. fernaldi (Murray) (this study) } \\
\text { Smith }\end{array}$ & $\begin{array}{l}\text { Angola } \\
\text { Congo } \\
\text { Europe, North } \\
\quad \text { Africa }\end{array}$ \\
\hline
\end{tabular}


pro- and mesothoracic tarsi lengthened to filaments. Caudal margins of abdomen with about 3 short spinulae and one long spine each. A pair of setae on IX abdominal sternite extend to posterior margin of XI. A pair of median setae on $\mathrm{XI}$ segment twice as long as those on the pleurite.

Material examined.-Voucher specimens: Adult male $0^{\prime}$ Iowa, Sioux City, USA, N42 $32.5^{\prime}$, W096 ${ }^{\circ} 23.5^{\prime}, 01.1 x .2008$ (G. K. Lechner) University Museum of Natural History, Oxford, UK. Neotenic 우 04.ix.2008, same data as above.
Strepsiptera Paraxenos lugubris parasitic in A. fernaldi and A. pictipennis.A total of 387 first instar larvae of $\mathrm{P}$. lugubris were observed attached to $A$. fernaldi and A. pictipennis in July-October 2008 when females were making new nests, mass provisioning, and laying eggs (Table 1). One unstylopized female $A$. fernaldi was found near a burrow entrance carrying two $P$. lugubris first instar larvae. In this study, 58 of 111 female $(52 \%)$ and 21 of $73(29 \%)$ male $A$. fernaldi and A. pictipennis were stylopized. Stylopization by P. lugubris was independent of Ammo-
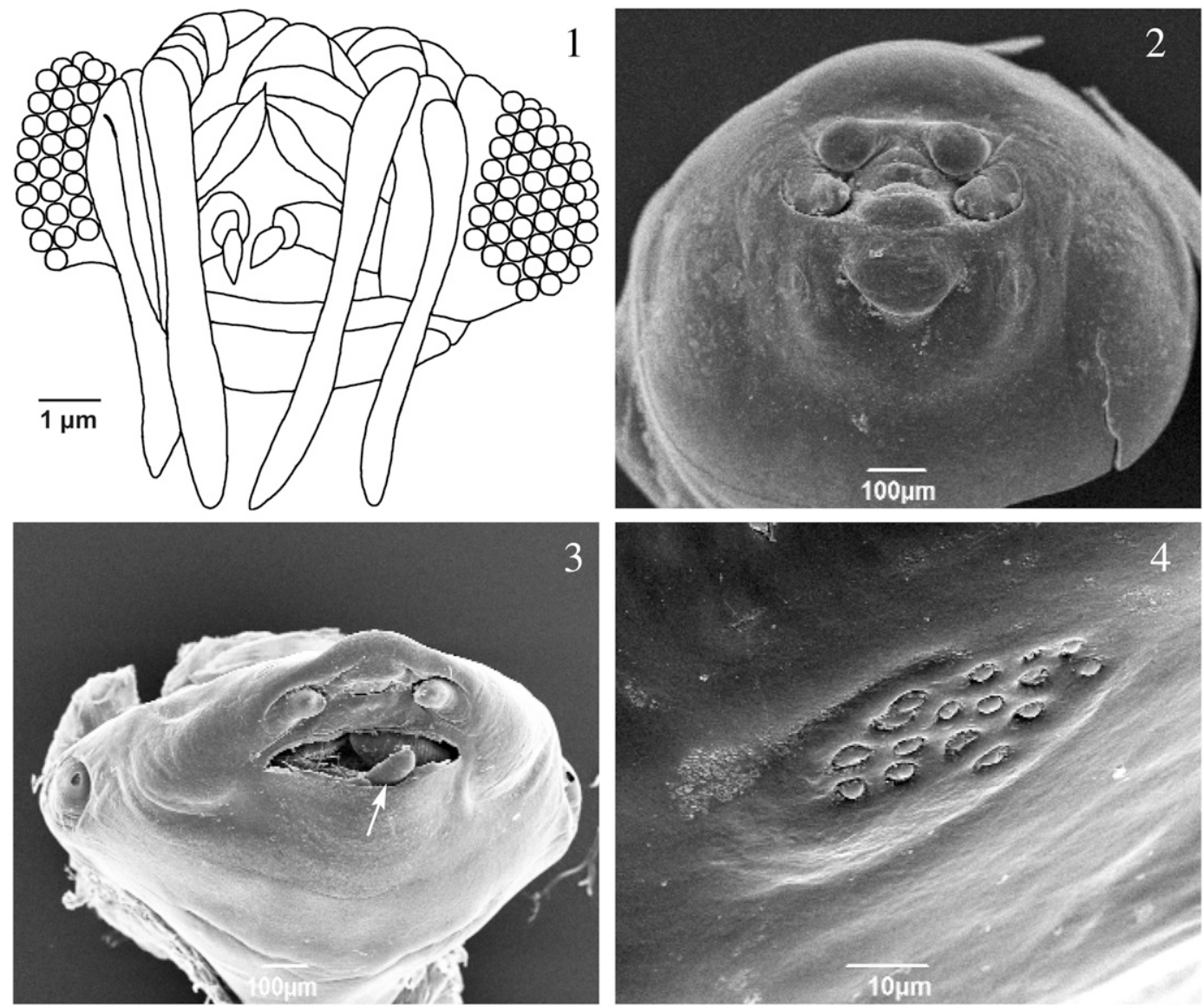

Figs. 1-4. Paraxenos lugubris, male (ventral view of head). Fig. 2. Paraxenos lugubris male (cephalotheca) (SEM). Fig. 3. Paraxenos lugubris female cephalothorax with first instar larva emerging from brood canal opening (arrow) SEM). Fig. 4. Nassonow's glands on Paraxenos lugubris female cephalothorax (SEM). 
phila sp. $\left(\mathrm{F}_{1,12}=1.74, P=0.23\right)$. Adult free-living male $P$. lugubris emerge from the endoparasitic pupa in June-October (evidenced by the empty puparia). The neotenic $P$. lugubris female extrudes its cephalothorax in the host in June-August and is then fertilized by the free-living male. The $P$. lugubris free-living first instar larvae emerge from the endoparasitic female in July-October (Fig. 11 - Life Cycle). Stylopization by $P$. lugubris is temporally and spatially patchy. Stylopization has been rare or absent at this site before and since 2008 (GLK, unpublished). Thus the high stylopization rate in 2008 provided an unprecedented opportunity to study phoresy in $P$. lugubris.

Method of transfer of $P$. lugubris first instar larva to the host larva in the nest.Phoresy of the first instar larva of $P$. lugubris by unstylopized Ammophila sp. is sex dependent. The relative proportion of unstylopized female Ammophila sp. carrying out phoretic first instars (19 of the 53 total unstylopised female hosts) is greater than that in males ( 8 of 52 unstylopised male hosts) $\left(\chi_{2}=2.67 ; P=0.10\right)$, suggesting biological and behavioral differences between unstylopized male and female hosts (Table 1), and, indeed, the preference for unstylopised female hosts which build and provision the nest. The first-instars observed attached to unstylopized female Ammophila sp. were found on the wings, legs and petiole (Figs. 10-11). They were collected between July and October, with the majority in September-October, thus confirming that phoresy occurred when nests were being built and provisioned, and before the final closure (Fig. 2).

First instars were also observed on stylopized wasps that are said to neither build nor provision a nest (Evans and West-Eberhart 1970). A total of 279 first instar larvae of $P$. lugubris were observed attached to 11 stylopized female hosts, all of which emerged from the neotenic female $P$. lugubris parasitic in these wasps. Only $15 \%$ of unstylopized male wasps were observed carrying first instar larvae of $P$. lugubris.

Superparasitism.-Of the total number of Ammophila sp. $(\mathrm{n}=184)$ collected, 79 were stylopized (Table 2), and, of these, 38 were superparasitized (Table 2). Superparasitism by combinations of both male and female strepsipterans occurs purely by chance $(\mathrm{F} 4,9=2.35, P=0.13)$. There is no evidence that parasitism by one sex increases or decreases the likelihood of superparasitism by the other. (Table 2).

\section{DisCUSSION}

Strepsiptera parasitize a wide range of hosts, and have evolved unique mechanisms to enable them to exploit thirty four families of Insecta (Kathirithamby 2009). In the Palaearcic region, males of the strepsipteran $X$. vesparum emerge in the autumn to inseminate the neotenic females that overwinter as endoparasites in gynes. However, in solitary bees and wasps the male and female strepsipterans overwinter as endoparasites in the prepupal hosts. The next spring, on emergence of the host, the free-living adult male strepsipteran would complete development and emerge and inseminate the endoparasitic, neotenic females. The female then produces first instars vivparously, extending the host life cycle as needed to complete the strepsipteran life cycle. This unique life history strategy is termed macrynobiosis (Kathirithamby 2009) and occurs in all strepsipterans. Strepsipterans co-adapt to the life history strategies of the numerous hosts they parasitize.

Strepsiptera are the only true parasitoids of the solitary hunting wasp Ammophila sp. The elaborate nest building, cleaning, provisioning behavior and the final sealing of the cell carried out by 

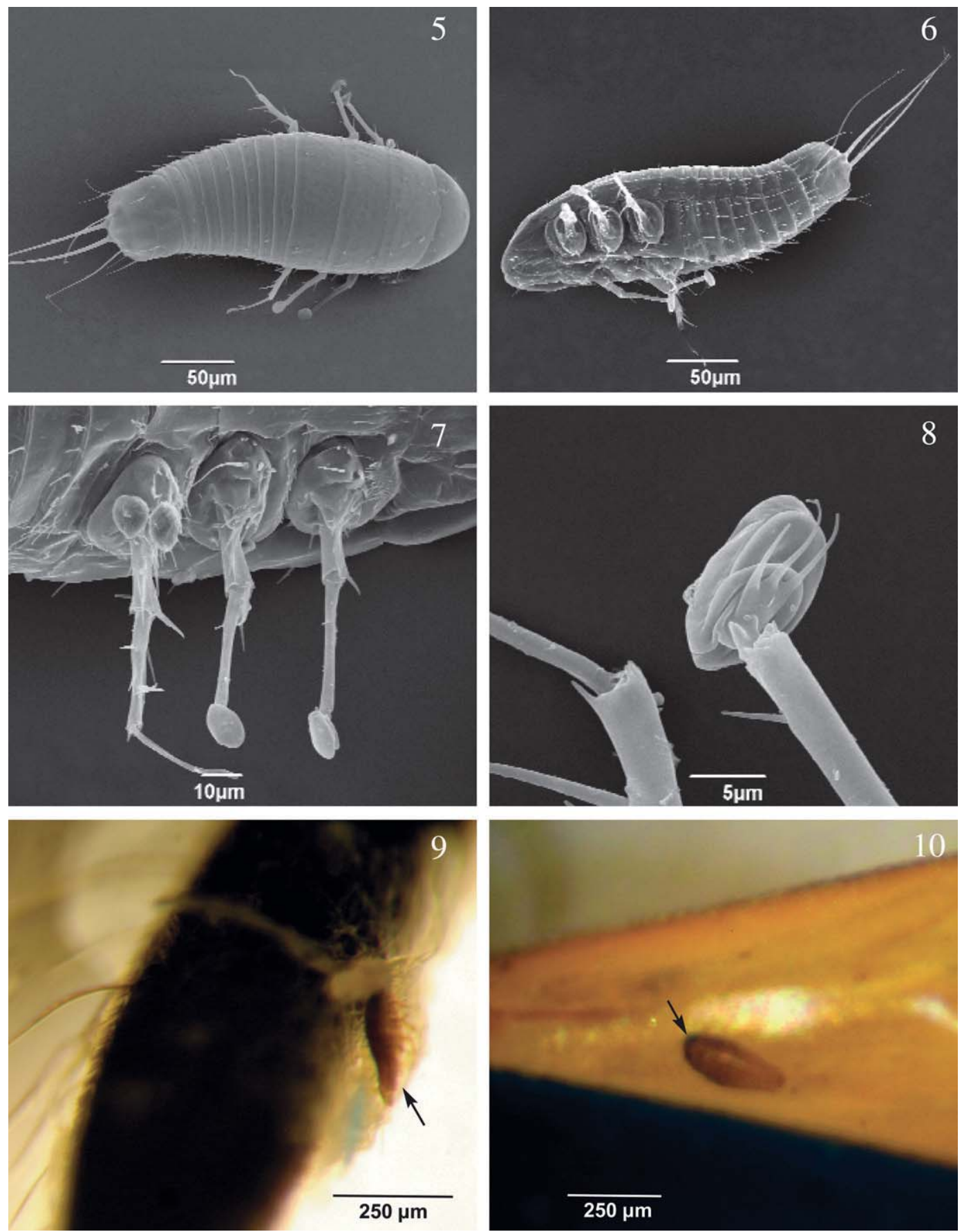

Figs. 5-10. Paraxenos lugubris SEM of first instar larva (dorsal view). Fig. 6. Paraxenos lugubris SEM of first instar larva (ventral view). Fig. 7. Paraxenos lugubris SEM of first instar larva (pro-, mesometathorcacic legs). Fig. 8. Paraxenos lugubris SEM of first instar larva (mesothoracic leg). Fig. 9. Paraxenos lugubris first instar attached to leg of Ammophila sp. Fig. 10. Paraxenos lugubris attached to petiole of host Ammophila sp. 


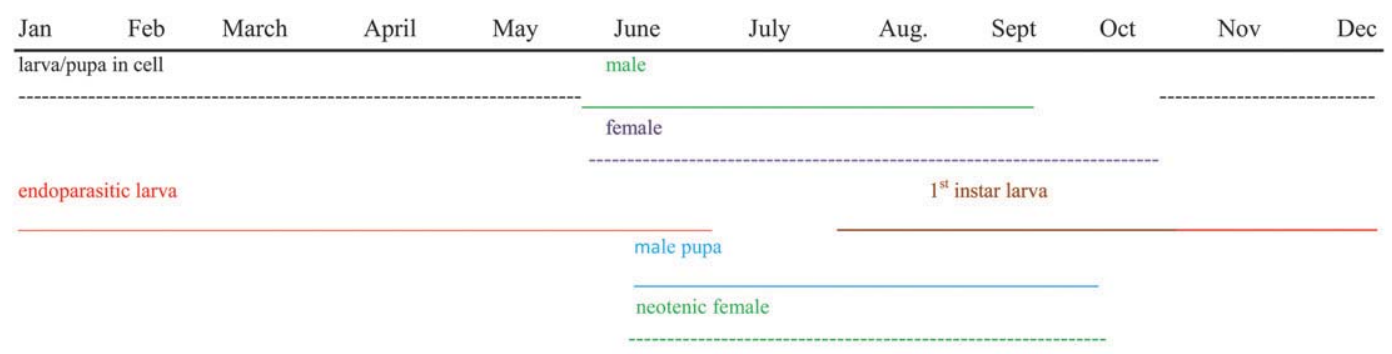

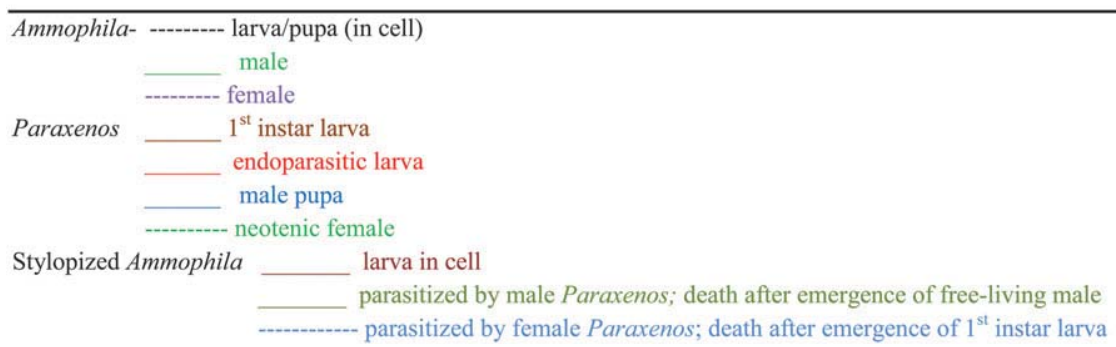

Fig. 11. Life cycle of Ammophila sp. and the strepsipteran parasitoid Paraxenos lugubris (Pierce).

female Ammophila sp. prevent the success of most parasites/parasitoids. The mother detects mortality factors (such as parasitoids) during these activities (Rosenheim 1987), upon which, termination of feeding and abandoning of larva ensues (Field and Brace 2004). As true parasitoids of Ammophila, Strepsiptera are an exception in that they are able to enter the solitary nest and parasitize hosts.

Horizontal transmission does not take place in a nest that supports one generation. Free-living first instar larvae are the host seeking stage, and have little chance of finding an egg/larva of a host to parasitize if they remain on the host wasp from which they have emerged. Therefore Strepsiptera that parasitize hosts whose immature stages develop inside nests, must have a mechanism to transport the strepsipteran first instars to nests where the immature hymenopteran stages are present. This process takes place either by the host stylopized with a mature endoparsitic female strepsipteran moving near a nest which contains host larvae; or by phoresy. However, only rare sightings of phoresy have so far been recorded (e.g., Maeta et al. 2001, Hughes et al. 2003). Here we show that Strepsiptera have even adapted to the life cycle of the solitary hunting wasps which carry out scrupulous nest building and display cleaning habits that are supposed to minimize parasitization. To find a host egg or larva, the strepsipteran must be phoretic on an unstylopized female host which would build a nest and provision it. We speculate that the first instar larvae of $P$. lugubris are deposited onto flowers and from here they move to an unstylopized provisioning $A$. fernaldi or $A$. pictipennis female wasp, while it is on a foraging trip.

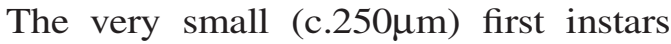
would then be transported by phoresy, literally by being attached to an un- 
stylopized provisioning female wasp as documented in this study. They thus pass undetected into a cell together with this provisioning wasp. On entering the cell, they parasitize the single egg or larva and remain endoparasitic, while the host metamorphoses from larva to pupa. In the spring, when the host emerges from the cell, the endoparasitic strepsipteran begins pupation if male, or becomes a neotenic female.

Phoresy of adult parasites/predators is of little advantage if the host lays single eggs, and all known species with phoretic behavior attack hosts that lay masses of eggs (Clausen 1976). However, in Strepsiptera, as shown in this study, phoresy of multiple larvae to a single host egg/larva is compensated for by superparasitism.

In Ammophila, each nest is a single cell which remains sealed at most times and contains only a single host egg/larva which is mass provisioned. Phoresy of first instars on an unstylopized provisioning Ammophila female is therefore a better option for the transfer of first instars of Paraxenos sp. to the nest, since the first instar larvae can enter the cell discreetly, together with a provisioning female, during the time when the cell is open. This study has shown that greater numbers of female, rather than male Ammophila had first instar P. lugubris attached to them, and this occurred during the time when the females were building and provisioning the nest.

We speculate that the strepsipteran first instars, while on the flowers, detect the unstylopized provisioning female host wasp by chemical stimuli, which might explain the low numbers of unstylopized male wasps observed carrying first instars. It is also possible that the first instars attract the host: in a Meloidae beetle, the first instars attract a solitary male bee, and are then transferred to a female during mating (Saul-Gersheuz and Millar 2006).
However, the studies which would allow the observation of such a phenomenon are not possible for Strepsiptera, as they are cryptic, and large collections are rarely made during a single season, such as was the case in this study.

This cryptic nature of Strepsiptera has also passed unnoticed by biologists: hence the absence so far of records of stylopization in this group of intriguing hosts of solitary hunting wasps which, with their complicated and elaborate mechanisms of nest building and provisioning habit, provide an exception to Fabre's claim of an "obstinate check" to evolutionary process.

\section{ACKNOWLEDGMENTS}

We thank Michael Shaw for preparation of the SEMs and Malcolm Ryder for preparation of the figures. This work was supported by a Leverhulme Trust Grant (F/06 504/G) to JK.

\section{Literature Cited}

Batra, S. W. T. 1963. Organisms associated with Lasioglossum zephyrun (Hymenoptera: Halictidae). Journal of the Kansas Entomological Society 38: 267-389.

Clausen, C. P. 1976. Phoresy among entomophagous insects. Annual Review of Entomology 21: 343-368 (doi:10.1 146/annurev.en.21. 010176.002015).

Dufour, L. 1837. Recherches sur quelques entozoaires et larves parasites des insects Orthoptères et Hymenoptères. Annales de la Société des naturelles 7: 5-20.

Evans, H. E. and M. J. West-Eberhard. 1970. The Wasps. University of Michigan Press, Ann Arbor. 265 pp.

Fabre, H. 1920. More Hunting Wasps. New York. $376 \mathrm{pp}$.

Field, J. 1989a. Intraspecific parasitism and nesting success in the solitary wasp Ammophila sabulosa. Behaviour 110: 23-46. doi:10.1163/ 156853989 X00367

Field, J. 1989b. Alternative nesting tactics in a solitary wasp. Behaviour 110: 219-243. doi:10. 1163/156853989X00475 
Field, J. and S. Brace. 2004. Pre-social benefits of extended parental care. Nature 428: 650-652. doi:10.1038/nature02427

Hager, B. J. and F. E. Kurczewski. 1985. Cleptoparasitism of Ammophila harti (Fernald) (Hymenoptera: Specidae) by Senotainia vigilans Allen, with observations on Phrosinella aurifacies Downes (Diptera: Sarcophagidae). Psyche 92: 451-462. doi:10.1155/1985/47051

Houck, M. A. and B. M. O'Connor. 1971. Ecological and Evolutionary significance of phoresy in the Astigmata. Annual Review of Entomology 36: 611-636. doi:10.1146/annurev.en.36.010191. 003143

Hughes, D. P., L. Beani, S. Turillazi, and J. Kathirithamby. 2003. Prevalence of the parasite Strepsiptera in Polistes as detected by dissection of immatures. Insectes Sociaux 50: 62-68. doi:10.1007/s000400300010

Hughes-Schrader, S. C. 1924. Reproduction in Acroschismus wheeleri Pierce. Journal of Morphology 39: 157-205. doi:10.1002/jmor. 1050390106

Linsley, E. G. and J. W. McSwain. 1957. Observations on the habits of Stylops pacifica Bohart. University of California Publications in Entomology 11: 395-430.

Luna de Carvalho, E. 1959. Segunda contribuicao para o Estado dos Estrepsipteros Angolenses (Insecta, Strepsiptera). Publicacoes Culturais da Companhia de Diamantes Angola 41: 125-154.

Kathirithamby, J. 2009. Host-parasitoid associations in Strepsiptera. Annual Review of Entomology 54: 227-249. (doi: 10.1 146/annurev. ento.54. 110807.090525).

Maeta, Y., K. Goukon, K. Kitamura, and R. Miyanaga. 2001. Factors that determine the positions where Pseudoxenos iwatai Esaki (Strepsiptera: Stylopidae) extrudes from the host abdomen. Tijdschrift voor Entomologie 144: 203-215.

McMahon, D. P., A. Hayward, and J. Kathirithamby. 2009. The mitochondrial genome of the 'twisted-wing parasite' Mengenilla australiensis: a comparative study. BMC Genomics. doi:10.1186/1471-2164-10-603

Miller, R. S., A. M. Pearce, and K. M. O’Neill. 2009. Prevalence of stylopization of Sphex ichneumoneus (L.) (Hymenoptera: Sphecidae) by Paraxenos westwoodi (Templeton) (Strepsiptera:
Xenidae). Psyche 2009:1-4. doi:10.11155/ 2009/690125.

Pardi, L. 1946. Ricerche su Polistini. VI La "dominazione" e il ciclo ovarico annuale in Polistes gallicus (L.). Bollettino dell'. Instituto Entomologica Università di Bologna 15: 25-84.

Pasteels, J. J. 1956. Deux spècies des Strepsiptères parasitant un meme hôte. Bulletin des Annales Société Entomologie 92: 33-34.

Pierce, W. D. 1908. A preliminary review of he classification of the order Strepsiptera. Proceedings of the Entomological Society of Washington 9: 75-85.

Pierce, W. D. 1909. A monographic revision of the twisted winged insects comprising the order Strepsiptera Kirby. Bulletin of the United States National Museum 66: 1-232.

Pierce, W. D. 1911. Notes on the insects of the order Strepsiptera, with descriptions of new species. Proceedings of the United States National Museum 40: 487-511. doi:10.5479/ si.00963801.1834.487

Rosenheim, J. A. 1987. Nesting behavior and bionomics of a solitary ground-nesting wasp, Ammophila dysmica (Hymenoptera: Sphecidae): influence of parasite pressure. Annals of the Entomological Society of America 80: 739-749.

Saunders, S. S. 1872. Stylopidarum, ordinem Strepsipterorum Kirbii constituntium, mihi tamen potius Coleopterorum Familiae, Rhipiphordis Meloidisque propinquae, Monographia. Transactions of the Entomological Society of London 1872: 1-48.

Saul-Gershenz, L. S. and J. G. Millar. 2006. Phoretic nest parasites use sexual deception to obtain transfer to their host's nest. Proceedings of the National Academy of Sciences of the United States of America 103: 14039 14044. doi:10.1073/pnas.0603901103

Serini, B., D. P. Locatelli, M. Colombo and M. Spreafico. 1996. Strepsiptera larvae in pollen collected by Apis mellifera L. Bolletino di Zoologia agraria e di Bachicoltura series II, 28: 209-215.

Simon C., F. Frati, A. Bechenbach, B. Crespi, H. Liu, and P. Flook. 1994. Evolution, weighting, and phylogenetic utility of mitochondrial gene sequence and compilation of conserved polymerase chain reaction primers. Annals of the Entomological Society of America 87: 65 $1-701$. 
Appendix 1.The 390 nucleotide cox1 sequence amplified from two Paraxenos specimens stylopizing $A$. fernaldi and A. pictipennis, respectively.

5'TATTATTTATCAAGAAAGATTCAAAACCTCTACTTTTAGCCATTTAAGT ATAATCTTTGCCATAGGATCCATTAGATTTCTCGGCATAATCGTATGAGCCC ATCATATATTTACTACAGGTATAGATATTGACACTAAAGCTTACTTTTCTGCT TCAACAATAATTATTGGTGTACCTACAGGAATTAAAATTTTTAGATGATTAG TAACCTTGACTAGAGAAAAATTTGTCCAAAAATCTTCTCTTTTATGAGCTA TTGGATTTATCTACCTTTTCTCATTAGGAGGATTTACTGGTATTATTCTAGCT AATGCATCTATTGACACTATTCTTCATGATACATATTATGTAGTAGCCCACTT TCACTATGTCTTATCAATAGGAGCTA T3' 